\title{
ГЕОХИМИЧЕСКИЕ ТИПЫ ВОД ХВОСТОХРАНИЛИЩ СВИНЦОВО-ЦИНКОВЫХ МЕСТОРОЖДЕНИЙ ВОСТОЧНОГО ЗАБАЙКАЛЬЯ
}

\author{
Чечель Лариса Павловна', \\ Ipchechel@mail.ru \\ Замана Леонид Васильевич', \\ I.v.zamana@mail.ru \\ ' Институт природных ресурсов, экологии и криологии Сибирского отделения Российской академии наук, \\ Россия, 672014, г. Чита, ул. Недорезова, $16^{2}$.
}

Актуальность обсуждаемой темы обусловлена необходимостью решения задачи сохранения качества водных ресурсов в условиях воздействия горного производства.

Цель: изучение химического состава техногенно-трансформированных вод в районах отработки трех свинцово-цинковых месторождений Забайкалья и их геохимическая типизация.

Объекты: воды, формирующиеся в пределах хвостохранилищ Благодатского, Акатуевского и Кадаинского свинцово-цинковых месторождений, расположенных в Восточном Забайкалье.

Методы. Концентрации анионов измерялись турбидиметрическим, потенциометрическим, колориметрическим методами; катионы и металлы определялись атомно-адсорбционным методом и масс-спектрометрией с индуктивно-связанной плазмой (ICP-MS). Для определения состава равновесных вторичных минеральных фаз применялись диаграммы полей устойчивости алюмосиликатных минералов, построенные по методу, предложенному Р.М. Гаррелсом и Ч.Л. Крайстом.

Результаты. По соотношению основных ионов рассматриваемые воды относятся к гидрокарбонатному, сульфатно-гидрокарбонатному, гидрокарбонатно-сульфатному и сульфатному магниево-кальциевому и кальциево-магниевому химическим типам. Дренажные стоки свинцово-цинковых месторождений характеризуются значительным превышением содержаний металлов ( $A s, \mathrm{Zn}, \mathrm{Cd}, \mathrm{Pb}, \mathrm{Sb}, \mathrm{Mn}, \mathrm{Mo}, \mathrm{U}, \mathrm{La}$ ) над средним составом вод выщелачивания, с максимумом для мышьяка более чем в 800 раз и цинка - в 200 раз. Характер расположения точек состава вод на диаграммах устойчивости алюмосиликатных минералов свидетельствует об их насыщении относительно глинистых алюмосиликатов и кальцита, что с учетом особенностей их химического состава позволяет говорить о принадлежности последних к двум геохимическим типам - кремнисто-кальциево-магниевому и кремнистому карбонатно-кальциевому, ведущая роль в смене которых принадлежит интенсивности водообмена. Типизация аномальных гидрогеохимических полей в горнодобывающих регионах направлена на совершенствование эколого-геохимического мониторинга природных вод и может использоваться при разработке мероприятий по предотвращению загрязнения и очистке вод.

Ключевые слова:

Свинцово-цинковые месторождения, техногенные воды, хвостохранилища, минеральные равновесия, геохимический тип.

\section{Введение}

Последняя четверть ХХ в. отмечена началом активного количественного изучения водной миграции поллютантов в районах горной добычи. Ученые разных стран стали изучать проблему загрязняющего влияния складированных отходов добычи и переработки руд, дренажных стоков горных выработок на качество природных вод. При этом наиболее опасными были признаны отходы, содержащие сульфидные минералы [1]. Было установлено, что кислые дренажные стоки рудников содержат аномальные количества тяжелых металлов, оказывающих негативное воздействие на биотические компоненты ландшафта. Концентрации свыше 100 мг/л $\mathrm{Al}, \mathrm{Zn}, \mathrm{Cd}, \mathrm{Fe}$ и других металлов, значительный рост концентрации сульфатов, высокие содержания взвешенных частиц отмечаются в кислых сточных водах отработанных медных и свинцово-цинковых рудников в Македонии [2]. Кислотными дренажами угольных и золоторудных месторождений, характеризующихся увеличением концентрации сульфатов в среднем до 3,5 г/л и значительным ростом содержаний железа и других тяжелых металлов, загрязняются речные системы Южной Африки [3], повышенные со- держания мышьяка и сурьмы в водах и донных отложениях рек стали следствием золотодобычи на гигантском руднике Йеллоунайф (Канада) [4]. Отработка месторождений таких известных угледобывающих регионов, как Донецкий и Кузбасский угольные бассейны, способствует формированию шахтных дренажей с максимальной минерализацией до 17 г/л, $\mathrm{SO}_{4}-12$ г/л, $\mathrm{Na}-3,4$ г/л, $\mathrm{Mg}-1,2$ г/л, $\mathrm{Fe}-0,5$ г/л, $\mathrm{Mn}-0,07$ г/л [5, 6]. Подотвальные дренажи и воды хвостохранилища Тасеевского золоторудного месторождения (Восточное Забайкалье) характеризуются ростом концентраций (г/л): $\mathrm{SO}_{4}$ - до 5,54; $\mathrm{Al}$ - до 0,$15 ; \mathrm{Fe}$ - до 0,$77 ; \mathrm{Mn}$ - до 0,09, а также минерализации - до 7,30 г/л [7].

Негативное воздействие отработки месторождений на окружающую среду, помимо загрязнения подземных и поверхностных вод, проявляется в виде нарушения земной поверхности, загрязнения атмосферного воздуха, заболачивания и деградации почв, истощения растительности и загрязнения ее токсичными компонентами. Добыча ртути в округе Сюшань (Чунцин, Юго-Западный Китай) [8] представляет серьезную проблему в связи с загрязнением ртутью речных вод, почв и риса, яв- 
ляющегося одним из основных продуктов питания местного населения. Установлено сильное загрязнение сельскохозяйственных культур (овес, горох, редис) токсичными элементами, относящимися, согласно СанПиН 2.1.71287-03 [9], к первому $(\mathrm{Pb}, \mathrm{As})$, второму (Cu, Co, Mo) и третьему (W) классам опасности в г. Закаменск (Западное Забайкалье), на территории которого размещено горнообогатительное производство Джидинского W-Mo комбината [10].

Немалую угрозу представляют также нейтральные и щелочные рудничные стоки, формирующиеся в случае карбонатного состава вмещающих пород. Содержания $\mathrm{Pb}, \mathrm{Zn}$ и $\mathrm{Cd}$ в таких водах невысоки, но большую подвижность проявляют анионогенные высокотоксичные элементы, включающие $\mathrm{As}, \mathrm{Sb}, \mathrm{Se}$ и $\mathrm{Mo}[2,11-13]$.

Восточное Забайкалье - старейший горнорудный регион России, освоение рудных месторождений в нем начато с разработки серебряно-свинцовых руд и относится к 17 в. Здесь впервые в России были добыты свинец, цинк, серебро, олово, флюорит, молибден, вольфрам. В Забайкальском крае известно несколько десятков месторождений цинка и свинца, многие из которых отрабатывались в прошлом либо отрабатываются в настоящее время. Прилегающие к рудникам территории покрыты горными выработками, породными отвалами и хвостами обогатительных фабрик. Токсичные компоненты, поступая в окружающую среду, загрязняют все элементы ландшафтов и в первую очередь природные воды. В связи с этим изучение особенностей химического состава и степени техногенного преобразования вод, формирующихся в таких районах, несомненно, актуально и имеет важное практическое значение в решении задачи сохранения окружающей среды.

\section{Объекты и методы исследований}

В 2013 и 2015 гг. было проведено гидрогеохимическое опробование трех разрабатывавшихся ранее свинцово-цинковых месторождений - Бла-

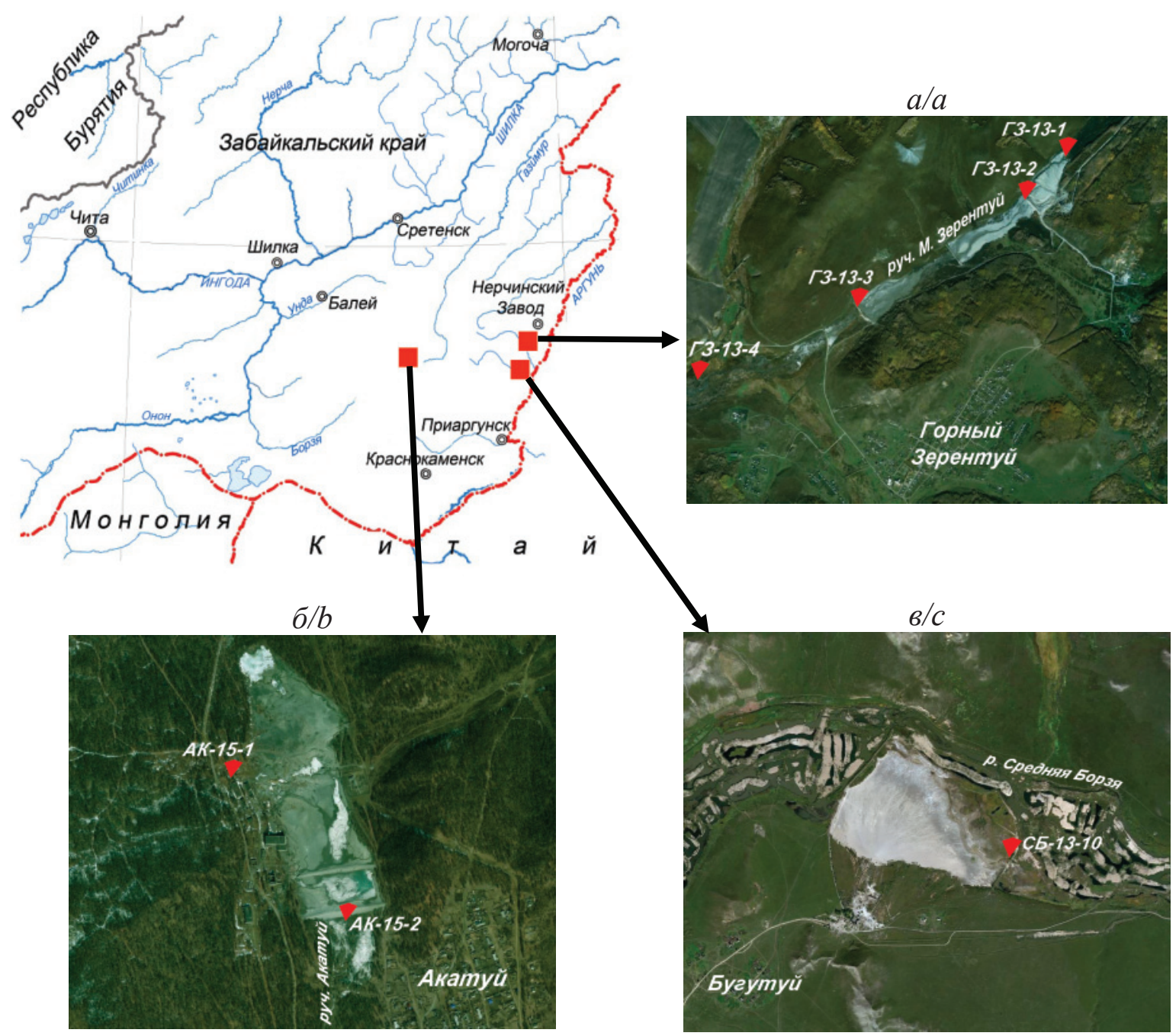

Pис.1. Местоположение объектов исследования и пункты их опробования. Хвостохранилища: а) Благодатского; б) Акатуевского; в) Кадаинского месторождений

Fig. 1. Location of the objects of research and their testing points. Tailings of: a) Blagodatskoe; b) Akatuevskoe; c) Kadainskoe deposits 
годатского, Акатуевского и Кадаинского, расположенных в пределах Приаргунского полиметаллического пояса (С.С. Смирнов, 1932) в юго-восточной части Забайкальского края (рис. 1).

На Благодастком месторождении были опробованы воды ручья Малый Зерентуй, в долине которого в период отработки месторождения располагалось хвостохранилище. Пробы отбирались выше хвостохранилища, в его центральной и нижней частях и под нижней дамбой, замыкающей хвостохранилище (рис. $1, a$ ). На Акатуевском месторождении были опробованы воды дренажа штольни в западном борту хвостохранилища, которые затем растекаются по его поверхности и далее фильтруются через пески хвостохранилища, и выхода фильтрационных вод под его нижней дамбой (рис. 1, б). На Кадаинском месторождении опробован пруд хвостохранилища в его нижней части (рис. 1, в).

Рассматриваемые свинцово-цинковые месторождения относятся к рудной формации галенитсфалерит-карбонатно-кварцевой метасоматических залежей и карбонатных пород нижнепалеозойского возраста $[14,15]$. Рудные тела месторождений залегают среди карбонатных пород нижнего палеозоя (доломиты и известняки, переслаивающиеся с алевролитами и аргиллитами) и локализуются в контактах карбонатных и алюмосиликатных пород и внутри карбонатных пород, в местах пересечения разломов. В первом случае они, как правило, представлены согласными пластообразными залежами, во втором - штоками и линзами. В составе жильных минералов большую роль играют различные карбонаты - доломит, анкерит, кальцит. Среди типов полиметаллических руд преобладают пирит-галенит-сфалеритовый (Благодатское месторождение) и галенит-сфалеритовый (Кадаинское и Акатуевское месторождения).

Химико-аналитические исследования водных проб выполнялись в аттестованной лаборатории Института природных ресурсов, экологии и криологии СО РАН (г. Чита) общепринятыми методами: потенциометрией, колориметрией, турбидиметрией. Определение концентраций металлов проводилось атомно-абсорбционным методом на спектрофотометре SOLAAR M6. Дополнительно выполнялся анализ водных проб методом ICP-MS в Институте геохимии им. А.П. Виноградова СО РАН (г. Иркутск).

При выделении геохимических типов вод за основу принята классификация, предложенная С.Л. Шварцевым [16], построенная на принципе существования строгой парагенетической зависимости между составом водного раствора и вторичной минеральной фазы, формируемой этими водами на каждой ступени развития системы «вода-порода». Для определения равновесных минеральных фаз в работе применялись диаграммы полей устойчивости минералов, построенные по методу, предложенному Р.М. Гаррелсом и Ч.Л. Крайстом [17].

\section{Результаты исследований и их обсуждение}

Данная работа является продолжением и развитием исследований, изложенных в более ранних публикациях [18 и др.], в которых были освещены особенности химического состава вод полиметаллических месторождений и приведены результаты расчетов неорганических форм миграции компонентов.

Воды месторождений, несмотря на преимущественно сульфидный состав руд, характеризуются нейтральными и слабощелочными значениями $\mathrm{pH}$ (табл. 1), что обусловлено высоким нейтрализующим потенциалом вмещающих карбонатных пород и минералов, присутствующих в рудах. По степени минерализации воды преимущественно пресные. Исключением является пруд Кадаинского хвостохранилища (сумма ионов 1,8 г/л), отсутствие стока из которого определяло более продолжительное время взаимодействия воды с кеком хвостохранилища и способствовало возрастанию доли испарительного концентрирования в росте ее минерализации.

Таблица 1. Физико-хилические паралетры состава вод хвостохранилищ свиниово-иинковых месторождений ЮгоВосточного Забайкалья (мг/л)

Table 1. Physical and chemical parameters of water composition of lead-zinc deposits tailings $(\mathrm{mg} / \mathrm{l})$

\begin{tabular}{|c|c|c|c|c|c|c|c|}
\hline \multirow[b]{2}{*}{$\begin{array}{l}\text { Параметр } \\
\text { Parameter }\end{array}$} & \multicolumn{7}{|c|}{ Номер пробы/Sample number } \\
\hline & $\begin{array}{l}\overrightarrow{0} \\
\dot{0} \\
\dot{0}\end{array}$ & 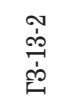 & $\begin{array}{l}\infty \\
\stackrel{\infty}{7} \\
\dot{\rho}\end{array}$ & 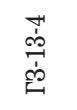 & 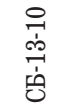 & $\frac{7}{\text { 它 }}$ & 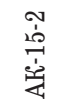 \\
\hline $\mathrm{pH}$ & 7,70 & 8,04 & 8,26 & 8,30 & 7,80 & 7,58 & 7,25 \\
\hline Eh, $m V$ & 295 & - & 293 & 255 & 262 & 220 & -92 \\
\hline $\mathrm{HCO}_{3}^{-}$ & 215,0 & 216,0 & 204,0 & 448,0 & 73,2 & 281,2 & 262,9 \\
\hline $\mathrm{SO}_{4}{ }^{2-}$ & 33,0 & 73,5 & 111,3 & 107,5 & 1150 & 307,5 & 478,2 \\
\hline $\mathrm{Cl}^{-}$ & 2,20 & 2,30 & 2,20 & 2,00 & 3,70 & 1,52 & 1,60 \\
\hline $\mathrm{F}^{-}$ & 0,21 & 0,20 & 0,21 & 0,21 & 0,72 & 0,36 & 0,49 \\
\hline $\mathrm{NO}_{2}^{-}$ & 0,012 & 0,012 & 0,014 & 0,015 & 0,013 & 0,011 & 0,012 \\
\hline $\mathrm{NO}_{3}{ }^{-}$ & 0,62 & 0,58 & 0,53 & 1,15 & $<0,62$ & 0,31 & 1,49 \\
\hline $\mathrm{NH}_{4}$ & 0,29 & 0,26 & 0,20 & 0,20 & 0,13 & 0,15 & 0,28 \\
\hline $\mathrm{Ca}^{2+}$ & 74,7 & 57,0 & 69,3 & 86,8 & 459,2 & 147,7 & 155,1 \\
\hline $\mathrm{Mg}^{2+}$ & 2,32 & 24,4 & 26,2 & 58,9 & 112,5 & 43,3 & 42,9 \\
\hline $\mathrm{Na}^{+}$ & 5,02 & 4,82 & 4,67 & 6,47 & 16,2 & 7,25 & 12,8 \\
\hline $\mathrm{K}^{+}$ & 0,96 & 0,91 & 1,05 & 0,67 & 5,73 & 1,21 & 4,49 \\
\hline $\mathrm{Si}$ & 5,13 & 4,96 & 4,69 & 3,31 & 1,10 & 6,65 & 10,3 \\
\hline $\begin{array}{c}\text { इионов } \\
\text { Eions }\end{array}$ & 333,4 & 379,1 & 418,9 & 710,6 & 1821 & 789,7 & 958,0 \\
\hline 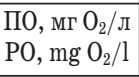 & 6,82 & 6,30 & 5,35 & 11,2 & 2,42 & 0,58 & 1,48 \\
\hline $\mathrm{P}_{\text {об. }} / \mathrm{P}_{\text {total }}$ & 0,058 & 0,058 & 0,062 & 0,06 & 0,78 & 0,078 & 0,13 \\
\hline
\end{tabular}

Примечание: ПО - окисляелость перманганатная; ГЗ - Благо датское, СБ - Кадаинское, $А К$ - Акатуевское месторождения; ционов- минерализация

Note: PO - permanganate oxidation; T3 - Blagodatskoe, CБ - Kadainskoe, AK-Akatuevskoe deposits; Lions - water mineralization.

После прохождения вод через пески Благодатского и Акатуевского хвостохранилищ фиксируется заметное обогащение их ионами сульфатов, гидрокарбонатов, магния и другими (табл. 1), что ве- 
дет к росту минерализации в 2,1 и 1,2 раза соответственно и к смене химического состава. Так, формулы химического состава имели вид:

- из ручья на входе в Благодатское хвостохранилище -

$$
\mathrm{M} 0.33 \frac{\mathrm{HCO}_{3} 82 \mathrm{SO}_{4} 16 \mathrm{Cl} 1}{\mathrm{Ca} 90 \mathrm{Mg} 5 \mathrm{Na} 5} \mathrm{pH} 7.70 ;
$$

- на выходе -

$$
\mathrm{M} 0.71 \frac{\mathrm{HCO}_{3} 76 \mathrm{SO}_{4} 23 \mathrm{Cl} 1}{\mathrm{Mg} 51 \mathrm{Ca} 45 \mathrm{Na} 3} \mathrm{pH} 8.30 \text {; }
$$

- из штольни перед Акатуевским хвостохранилищем -

$$
\mathrm{M} 0.79 \frac{\mathrm{SO}_{4} 58 \mathrm{HCO}_{3} 42}{\mathrm{Ca} 65 \mathrm{Mg} 32 \mathrm{Na} 3} \mathrm{pH} 7.58
$$

- на выходе -

$$
\text { M0.96 } \frac{\mathrm{SO}_{4} 69 \mathrm{HCO}_{3} 30}{\mathrm{Ca} 65 \mathrm{Mg} 30 \mathrm{Na} 5} \mathrm{pH} 7.25 .
$$

Изменения значений $\mathrm{pH}$ при этом имели разнонаправленный характер - возрастали при прохождении вод через пески Благодатского и понижались при прохождении через пески Акатуевского хвостохранилищ (табл. 1). Формула химического состава вод пруда Кадаинского хвостохранилища имела вид: M1.82 $\frac{\mathrm{SO}_{4} 95 \mathrm{HCO}_{3} 5}{\mathrm{Ca} 69 \mathrm{Mg} 28 \mathrm{Na} 2} \mathrm{pH} 7.80$. Этим водам характерны максимальные из изученных концентрации макрокомпонентов и минерализации (табл. 1).

Миграция тяжелых металлов в нейтральных и щелочных средах ограничена низкой растворимостью их гидроксидов, что отражается на содержаниях этих компонентов в водах. Максимальные концентрации металлов, достигающие миллиграммовых значений, фиксируются в редких случаях, составляя, как правило, первые десятки, единицы и менее мкг/л (табл. 2). В отличие от рассматриваемых вод в кислых сульфатных дренажных стоках вольфрамовых, молибденовых и золоторудных месторождений, залегающих в алюмосиликатных породах, были установлены содержания металлов на уровне единиц, десятков и сотен мг/л $[7,19]$.

Выяснение геохимической специфики природных вод, оценка их экологического состояния осуществляется, как правило, посредством сравнения показателей состава вод с кларками гидросферы (кларки речных и морских вод либо вод оз. Байкал), предельно-допустимыми (ПДК) или фоновыми показателями [20-22].

В данной работе нами применена нормализация данных их химического анализа относительно среднего состава вод выщелачивания [23]. Наибольшие превышения концентраций компонентов над средним составом вод выщелачивания свойственны металлам, относящимся к группе рудообразующих элементов рассматриваемых месторож- дений - Zn, Pb, Fe, As (табл. 2). Максимальные превышения зафиксированы для мышьяка (>800 раз) в линейной разгрузке вод под нижней дамбой Акатуевского хвостохранилища, а также цинка (>200 раз) и кадмия (почти в 100 раз) в водах пруда хвостохранилища Кадаинского месторождения (рис. 2, б).

Таблица 2. Концентрации металлов в водах хвостохранилищ,

\begin{tabular}{|c|c|c|c|c|c|c|c|}
\hline \multirow{2}{*}{$\begin{array}{l}\text { Параметр } \\
\text { Parameter }\end{array}$} & \multicolumn{7}{|c|}{ Номер пробы/Sample number } \\
\hline & ГЗ-13-1 & ГЗ-13-2 & ГЗ-13-3 & ГЗ-13-4 & СБ- $13-10$ & AK-15-1 & AK-15-2 \\
\hline $\mathrm{Li}$ & 6,70 & 7,30 & 7,30 & 10,1 & 29,0 & 11,5 & 11,9 \\
\hline $\mathrm{Be}$ & 0,13 & 0,015 & 0,0091 & 0,017 & 0,0029 & 0,030 & 0,016 \\
\hline $\mathrm{Al}$ & 945,0 & 28,0 & 18,0 & 174,0 & 14,2 & 38,0 & 19,0 \\
\hline Sc & 0,14 & 0,0088 & 0,006 & 0,020 & 0,019 & 0,033 & 0,02 \\
\hline $\mathrm{Ti}$ & 7,30 & 0,46 & 0,25 & 3,33 & 0,27 & 1,22 & 0,63 \\
\hline $\mathrm{V}$ & 1,96 & 0,51 & 0,14 & 0,86 & 0,03 & 0,24 & 0,22 \\
\hline $\mathrm{Cr}$ & 1,28 & 0,52 & 0,39 & 0,43 & 0,64 & 0,13 & 0,15 \\
\hline $\mathrm{Mn}$ & 37,0 & 54,0 & 220,0 & 49,0 & 1106 & 17,0 & 2361 \\
\hline $\mathrm{Fe}$ & 852,0 & 88,0 & 177,0 & 269,0 & 87,0 & 66,0 & 8435 \\
\hline $\mathrm{Ni}$ & 1,76 & 2,99 & 2,28 & 1,46 & 11,8 & 7,20 & 2,10 \\
\hline Co & 0,51 & 0,40 & 0,44 & 0,24 & 3,61 & 0,09 & 1,05 \\
\hline $\mathrm{Cu}$ & 2,05 & 5,30 & 13,8 & 0,50 & 3,51 & 3,30 & 2,00 \\
\hline $\mathrm{Zn}$ & 53,0 & 412,0 & 982,0 & 2,82 & 7846 & 2111 & 425,0 \\
\hline $\mathrm{Ga}$ & 0,25 & 0,02 & 0,04 & 0,04 & 0,10 & 0,01 & 0,14 \\
\hline As & 18,0 & 28,0 & 99,0 & 2,79 & 7,50 & 60,0 & 1097 \\
\hline $\mathrm{Se}$ & 0,16 & 0,11 & 0,30 & 0,34 & 0,18 & 1,51 & 0,06 \\
\hline $\mathrm{Br}$ & 7,90 & 10,4 & 8,60 & 12,6 & 41,0 & 7,80 & 7,50 \\
\hline $\mathrm{Rb}$ & 1,37 & 0,64 & 0,57 & 0,50 & 13,8 & 3,11 & 2,70 \\
\hline $\mathrm{Sr}$ & 212,0 & 226,0 & 241,0 & 369,0 & 2526 & 567,0 & 1148 \\
\hline $\mathrm{Zr}$ & 0,28 & 0,13 & 0,09 & 0,36 & 0,02 & 0,03 & 0,08 \\
\hline $\mathrm{Nb}$ & 0,02 & 0,004 & 0,002 & 0,01 & 0,002 & 0,004 & 0,004 \\
\hline Mo & 4,57 & 6,60 & 6,10 & 0,23 & 2,21 & 3,07 & 5,90 \\
\hline $\mathrm{Ag}$ & 0,004 & 0,08 & 0,06 & 0,002 & 0,03 & 0,04 & 0,008 \\
\hline $\mathrm{Cd}$ & 0,18 & 1,02 & 2,66 & 0,009 & 19,0 & 1,70 & 0,68 \\
\hline $\mathrm{Sb}$ & 2,46 & 8,60 & 25,0 & 0,56 & 19,0 & 3,36 & 0,91 \\
\hline $\mathrm{Cs}$ & 0,10 & 0,07 & 0,022 & 0,02 & 0,35 & 0,73 & 0,14 \\
\hline $\mathrm{Ba}$ & 27,0 & 25,0 & 27,0 & 31,0 & 21,0 & 8,30 & 67,0 \\
\hline $\mathrm{La}$ & 0,98 & 0,07 & 0,04 & 0,18 & 0,02 & 0,06 & 0,07 \\
\hline $\mathrm{Pb}$ & 7,90 & 42,0 & 150,0 & 0,19 & 57,0 & 2,56 & 14,4 \\
\hline Th & 0,05 & 0,007 & 0,005 & 0,02 & 0,008 & 0,01 & 0,01 \\
\hline $\mathrm{U}$ & 0,85 & 0,88 & 0,77 & 1,62 & 0,45 & 4,52 & 1,01 \\
\hline
\end{tabular}
свиниово-иинковых месторождений (мкг/л)

Table 2. Metal concentrations in the waters of tailings ponds of lead-zinc deposits $(\mu \mathrm{g} / l)$

Ряды распределения компонентов относительно среднего состава вод выщелачивания в порядке их убывания имеют вид: $\mathrm{As}>\mathrm{Pb}>\mathrm{Sb}>\mathrm{Zn}>\mathrm{Cd}>\mathrm{Mn}>$ $\mathrm{Mo}>\mathrm{Al}>\mathrm{La}>\mathrm{Sr}>\mathrm{Cu}>\mathrm{U}-$ на Благодатском, $\mathrm{As}>\mathrm{Zn}>$ $\mathrm{Mn}>\mathrm{Fe}>\mathrm{Sr}>\mathrm{Cd}>\mathrm{U}>\mathrm{Pb}>\mathrm{Sb}>\mathrm{Mo}>\mathrm{Cs}>\mathrm{Se}>\mathrm{Co}-$ на Акатуевском (рис. 2, a), $\mathrm{Zn}>\mathrm{Cd}>\mathrm{Mn}>\mathrm{Sb}>\mathrm{Sr}>\mathrm{Pb}>$ $\mathrm{Co}>\mathrm{As}>\mathrm{Ni}>\mathrm{Rb}>\mathrm{Li}>\mathrm{Cs}>\mathrm{Mo}$ - на Кадаинском хвостохранилищах (рис. 2, б).

Положение данных химического состава техногенных вод на диаграммах полей устойчивости минералов показало их насыщенность относительно вторичных минеральных образований - каолинита, монтмориллонита, иллита, кальцита и одновременно их ненасыщенность относительно минералов первичных алюмосиликатных пород, за исключением $\mathrm{Mg}$-хлорита (рис. 3). 
$a / a$

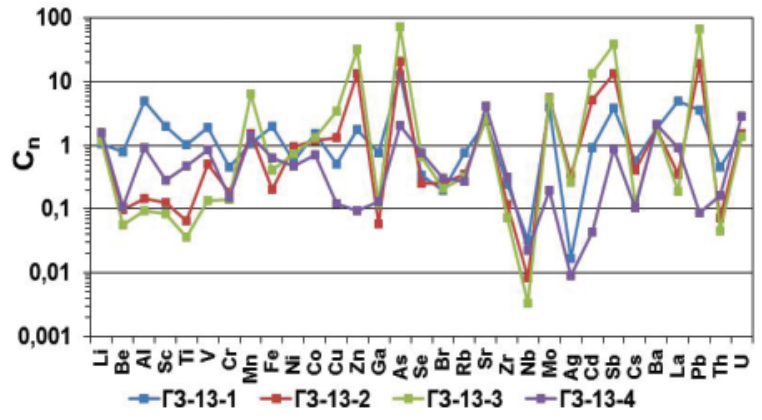

$6 / b$

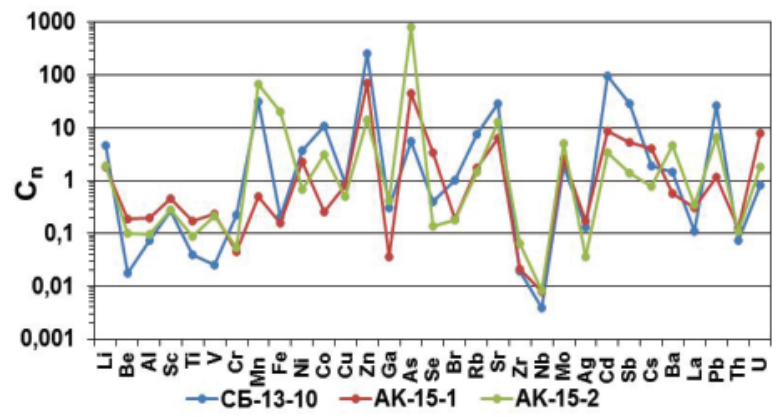

Рис. 2. Норлированные относительно среднего хилического состава вод выщелачивания значения кониентраций металлов в водах хвостохранилищ: а) Благодатского (ГЗ); б) Кадаинского (СБ) и Акатуевского (АК) месторождений

Fig. 2. Contents of metals normalized relative to the average chemical composition of the leaching waters in tailings of: a) Blagodatskoe ( $\Gamma 3$ ); b) Kadainskoe (CD) and Akatuevskoe (AK) deposits

Точки состава вод на диаграммах для кальциевых и магниевых минералов располагаются преимущественно в полях устойчивости кальцита, хлорита и монтмориллонита (рис. $3, a$, б); на диаграммах для натриевых и калиевых минералов - в полях устойчивости каолинита и иллита (рис. 3, ,, 2$)$. Равновесие с кальцитом и хлоритом в большей степени свойственно водам Благодатского и Кадаинского, с Са- и $\mathrm{Mg}$-монтмориллонитом - водам Акатуевского хвостохранилищ (рис. $3, a$, б). $K$ равновесию с каолинитом и иллитом склонны преимущественно воды, формирующиеся в отложениях Бла- годатского и Акатуевского хвостохранилищ (рис. 3, в, г). На двух диаграммах точки состава вод пруда Кадаинского хвостохранилища расположены в поле устойчивости гиббсита (рис. 3, в, г), что определяется пониженной активностью в растворе кремния. Тем не менее, благодаря способности алюминия к формированию устойчивых растворимых элементоорганических соединений, образование гиббсита маловероятно [24]. Преимущественно карбонатный состав вмещающих оруденение отложений, а также присутствие карбонатных минералов в составе рудных тел способствуют бы-
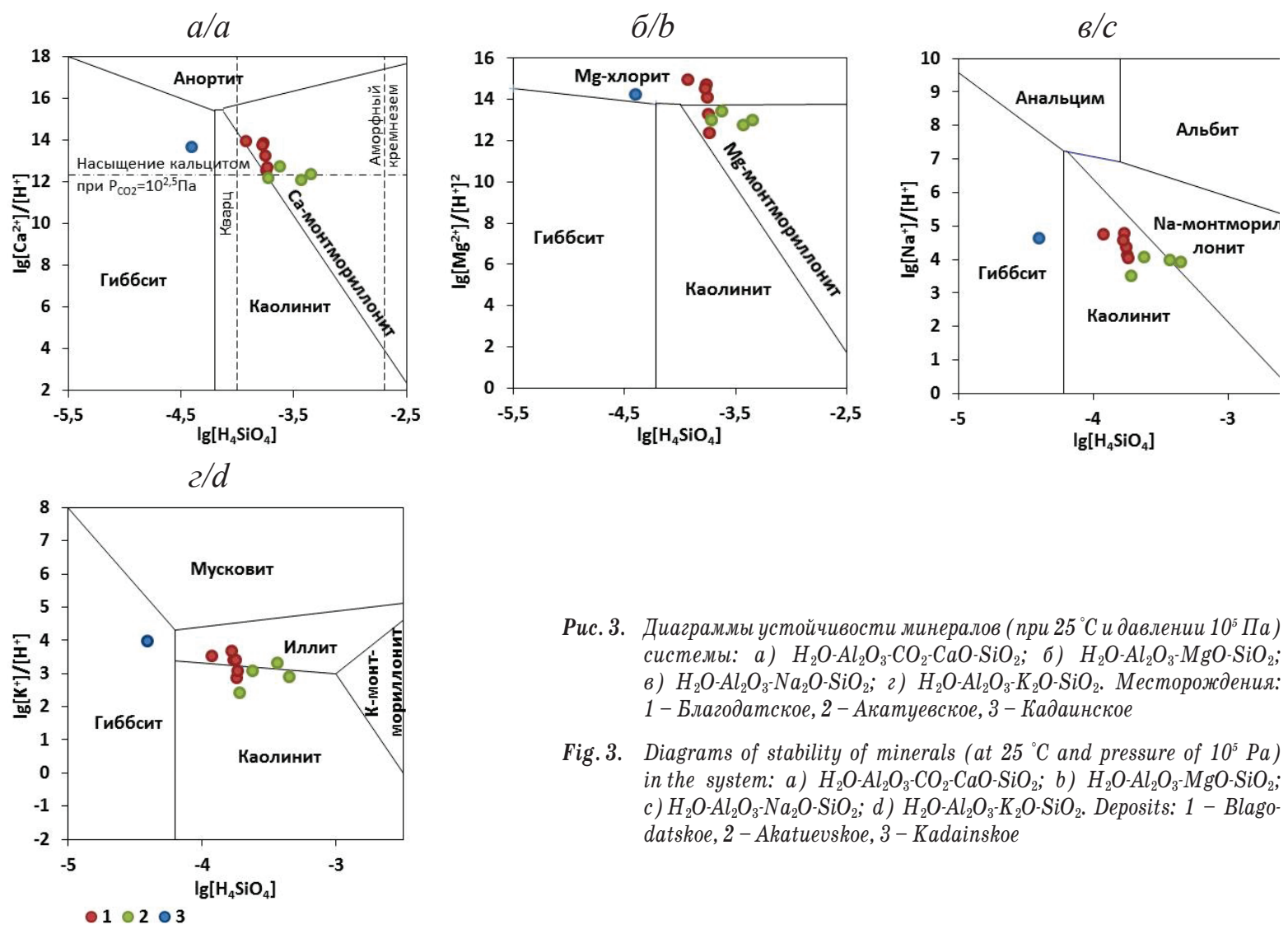

Pис. 3. Диаграмлы устойчивости минералов (при $25^{\circ} \mathrm{C}$ и давлении $10^{5}$ Па) cuстемы: a) $\mathrm{H}_{2} \mathrm{O}-\mathrm{Al}_{2} \mathrm{O}_{3}-\mathrm{CO}_{2}-\mathrm{CaO}-\mathrm{SiO}_{2}$; б) $\mathrm{H}_{2} \mathrm{O}-\mathrm{Al}_{2} \mathrm{O}_{3}-\mathrm{MgO}-\mathrm{SiO}_{2}$; в) $\mathrm{H}_{2} \mathrm{O}-\mathrm{Al}_{2} \mathrm{O}_{3}-\mathrm{Na}_{2} \mathrm{O}-\mathrm{SiO}_{2}$; г) $\mathrm{H}_{2} \mathrm{O}-\mathrm{Al}_{2} \mathrm{O}_{3}-\mathrm{K}_{2} \mathrm{O}-\mathrm{SiO}_{2}$. Месторождения: 1 - Благодатское, 2 - Акатуевское, 3 - Кадаинское

Fig. 3. Diagrams of stability of minerals (at $25{ }^{\circ} \mathrm{C}$ and pressure of $10^{5} \mathrm{~Pa}$ ) in the system: a) $\mathrm{H}_{2} \mathrm{O}-\mathrm{Al}_{2} \mathrm{O}_{3}-\mathrm{CO}_{2}-\mathrm{CaO}-\mathrm{SiO}_{2}$; b) $\mathrm{H}_{2} \mathrm{O}-\mathrm{Al}_{2} \mathrm{O}_{3}-\mathrm{MgO}-\mathrm{SiO}_{2}$; c) $\mathrm{H}_{2} \mathrm{O}-\mathrm{Al}_{2} \mathrm{O}_{3}-\mathrm{Na}_{2} \mathrm{O}-\mathrm{SiO}_{2}$; d) $\mathrm{H}_{2} \mathrm{O}-\mathrm{Al}_{2} \mathrm{O}_{3}-\mathrm{K}_{2} \mathrm{O}-\mathrm{SiO}_{2}$. Deposits: 1 - Blagodatskoe, 2 - Akatuevskoe, 3 - Kadainskoe 
строму насыщению вод ионами $\mathrm{CO}_{3}{ }^{2-}$ и достижению их равновесия с кальцитом. Поступление компонентов в раствор происходит в результате гидролиза алюмосиликатных и растворения карбонатных пород.

Анализ данных по составу исследованных вод и характеру минерального равновесия позволяет говорить об их принадлежности к двум геохимическим типам - кремнисто-кальциево-магниевому и кремнистому карбонатно-кальциевому (табл. 3).

Таблица 3. Геохимические типы техногенных вод свинцово-иинковых месторождений

Table 3. Geochemical types of technogenic waters of lead-zinc deposits

\begin{tabular}{|c|c|c|}
\hline $\begin{array}{l}\text { Геохимический } \\
\text { тип } \\
\text { Geochemical type }\end{array}$ & $\begin{array}{c}\text { Необходимое } \\
\text { химическое условие } \\
\text { Required chemical } \\
\text { condition }\end{array}$ & $\begin{array}{c}\text { Основные параметры } \\
\text { состава вод } \\
\text { Main parameters of water } \\
\text { composition }\end{array}$ \\
\hline $\begin{array}{l}\text { Кремнисто- } \\
\text { кальциево- } \\
\text { магниевый } \\
\text { Silicon-calcium- } \\
\text { magnesium }\end{array}$ & $\begin{array}{l}\text { Равновесие } \\
\text { с монтмориллонитом, } \\
\text { иллитом } \\
\text { Equilibrium with } \\
\text { montmorillonite, illite }\end{array}$ & $\begin{array}{l}\text { Слабощелочные, пресные } \\
\text { Alkalescent with low water } \\
\text { salinity; pH=7,9; Eh=196; } \\
\mathrm{SiO}_{2}=10,7 ; \text { } \text { ионов } / \text { ions= } \\
=432 \text { мг/л (mg/l) }\end{array}$ \\
\hline $\begin{array}{l}\text { Кремнистый } \\
\text { карбонатно- } \\
\text { кальциевый } \\
\text { Siliceous } \\
\text { carbonate-calcium }\end{array}$ & $\begin{array}{l}\text { Равновесие } \\
\text { с кальцитом } \\
\text { и глинами } \\
\text { Equilibrium } \\
\text { with calcite and clays }\end{array}$ & $\begin{array}{l}\text { Околонейтральные } \\
\text { и слабощелочные, } \\
\text { пресные и солоноватые } \\
\text { Neutral and slightly } \\
\text { alkaline with low and eleva- } \\
\text { ted water salinity; pH=7,66; } \\
\text { Eh=132; } \mathrm{SiO}_{2}=14,5 ; \text {;ионов/ } \\
\text { Lions }=1058 \text { мг/л (mg/l) }\end{array}$ \\
\hline
\end{tabular}

Более высокая скорость водообмена и, как следствие, меньшая соленость вод $(<0,6$ г/л) ручья Мал. Зерентуй, дренирующего Благодатское хвостохранилище, а также стока штольни Акатуевского месторождения позволяют отнести их к кремнисто-кальциево-магниевому геохимическому типу. Химический состав их преимущественно гидрокарбонатный и сульфатно-гидрокарбонатный магниево-кальциевый. Это околонейтральные и слабощелочные воды ( $\mathrm{pH} 7,4-8,3)$ с минерализацией, варьирующей в пределах 0,33-0,53 г/л. Равновесный с этими водами вторичный минеральный комплекс представлен Са- и $\mathrm{Mg}$-монтмориллонитом и иллитом.

В остальных случаях воды отнесены к кремнистому карбонатно-кальциевому геохимическому типу с величиной минерализации $>0,7$ г/л, представленному тремя пунктами наблюдений - ручей Мал. Зерентуй ниже Благодатского, выход фильтрационных вод под нижней дамбой Акатуевского и пруд Кадаинского хвостохранилищ (табл. 1).

Воды этого подтипа околонейтральные и слабощелочные ( $\mathrm{pH} 7,25-8,30)$, по величине минерализации пресные и солоноватые (0,71-1,82 г/л), их химический состав сульфатно-гидрокарбонатный, гидрокарбонатно-сульфатный и сульфатный магниево-кальциевый. Им свойственно насыщение кальцитом и глинами (каолинит, монтмориллонит, иллит).

Наиболее показательными признаками выделенных геохимических типов техногенных вод свинцово-цинковых месторождений являются из- менения концентраций макрокомпонентов и минерализации при переходе от одного типа к другому. При этом в наибольшей степени (на порядок) возрастают концентрации ионов $\mathrm{SO}_{4}{ }^{2-}, \mathrm{Ca}^{2+}$ и $\mathrm{Na}^{+}$, что является закономерным результатом эволюции состава вод с ростом общей минерализации и обусловлено особенностями взаимодействия в системе «вода-кек», протекающего в условиях сочетания в минеральном составе хвостов сульфидной кислотопродуцирующей и карбонатной кислотонейтрализующей минерализации.

Кислотонейтрализующее воздействие карбонатной минерализации полиметаллических рудников обуславливает нейтральность, невысокие концентрации тяжелых металлов и кажущуюся, в связи с этим, «безопасность» их водных дренажей. Но, как известно, нейтральные и щелочные среды благоприятны для миграции таких высокотоксичных элементов, как мышьяк и сурьма, подверженных процессам метилирования с образованием значительно более токсичных форм, чем катионные [2, $10,11,25]$. Изучение рудничных и подотвальных стоков Южного Урала [26] показало практически повсеместное присутствие в них $\mathrm{Cd}, \mathrm{Hg}$, $\mathrm{As}$ и $\mathrm{Sb}$, имеющих минимальные ПДК в питьевых водах и представляющих, в связи с этим, значительную опасность при питьевом использовании, даже в случае их минимальных и, тем более, повышенных концентраций. $K$ примеру, таких, которые фиксировались в нейтральных и слабощелочных водах, дренирующих отвалы обработанных Sb руд в Capдинии (Италия), где концентрации сурьмы достигали 30, а мышьяка - 16 мг/л [27].

Содержания мышьяка и сурьмы в рассматриваемых водах достигали аномально высоких значений (табл. 2), в десятки и сотни раз превышая средние показания для вод выщелачивания. Поскольку хвостохранилища расположены вблизи населенных пунктов (рис. 1) существует реальная угроза попадания токсичных компонентов в воды либо загрязнения атмосферного воздуха от пылевого переноса.

\section{Заключение}

Особенностью изученных объектов является формирование вод в условиях сочетания в минеральном составе хвостов сульфидной и карбонатной минерализации. Их химический состав формируется в результате совместного действия процессов гидролиза алюмосиликатов, растворения карбонатов и выщелачивания сульфидов руд, обогащающих растворы химическими элементами, и последующего их удаления в виде вторичных новообразований.

Анионный состав рассматриваемых вод - гидрокарбонатный, сульфатно-гидрокарбонатный, гидрокарбонатно-сульфатный и сульфатный, катионный - магниево-кальциевый и кальциевомагниевый. Воды пресные и солоноватые, по величине щелочно-кислотного показателя $\mathrm{pH}$ - околонейтральные и слабощелочные. В микроэлементном составе дренажных стоков преобладают мышьяк, цинк, кадмий, свинец, сурьма и марганец. 
Исследованные воды находятся в состоянии равновесия с глинистыми минералами и кальцитом, на основании чего установлена их принадлежность к двум геохимическим типам - кремнистокальциево-магниевому и кремнистому карбона-

\section{СПИСОК ЛИТЕРАТУРЫ}

1. Waste-rock hydrogeology and geochemistry / R.T. Amos, D.W. Blowes, B.L. Bailey, D.C. Sego, L. Smith, A.M. Ritchie // Applied Geochemistry. - 2015. - V. 57. - P. 140-156. DOI: 10.1016/j.apgeochem.2014.06.020.

2. The Chemistry of Waters Associated with Metal Mining in Macedonia / D.M. Alderton, T. Serafimovski, B. Mullen, S. James // Mine Water and the Environment. - 2005. - V. 24. - № 3. P. 139-149. D0I: $10.1007 / \mathrm{s} 10230-005-0085-\mathrm{z}$.

3. McCarthy T.S. The impact of acid mine drainage in South Africa // S. Afr. J. Sci. - 2011. - V. 107. - P. 5-6. DOI: dx.doi.org/10.4102/sajs.v107i5/6.712.

4. Arsenic and antimony geochemistry of mine wastes and associated waters and sediments at the Giant Mine, Yellowknife, Northwest Territories, Canada / S.E. Fawcett, H.E. Jamieson, D.K. Nordstrom, R.B. McCleskey // Applied Geochemistry. 2015. - V. 62. - P. 3-17.

5. Гавришин А.И. Закономерности формирования химического состава шахтных вод и их влияние на геоэкологическую ситуацию (ш. Комиссаровская, Восточный Донбасс) // Геоэкология. Инженерная геология. Гидрогеология. Геокриология. 2015. - № 6. - C. 505-513.

6. Оценка техногенной нагрузки на бассейны рек горнодобывающего района в южной части Кузбасса / Е.Л. Счастливцев, А.А. Быков, Н.И. Юкина, С.Г. Пушкин // Геоэкология. Инженерная геология. Гидрогеология. Геокриология. - 2015. № 4. - С. 333-339.

7. Замана Л.В. Геохимия кислых дренажных вод золоторудных месторождений Восточного Забайкалья // Вода: химия и экология. - 2013. - № 8. - С. 92-97.

8. The impact of an abandoned mercury mine on the environment in the Xiushan region, Chongqing, southwestern China / X. Xu, Y. Lin, B. Meng, X. Feng, Z. Xu, Y. Jiang, W. Zhong, Y. Hu, G. Qiu // Appl. Geochem. - 2018. - V. 88. - Part B. P. 267-275. DOI: 10.1016/j.apgeochem.2017.04.005.

9. СанПиН 2.1.7.1287-03. Санитарно-эпидемиологические требования к качеству почв и грунтов. URL: http://files.stroyinf.ru/Data1/11/11782/ (дата обращения 30.05.2018).

10. Дорошкевич С.Г., Бардамова И.В. Фитотоксичность лежалых отходов обогащения сульфидно-вольфрамовых руд Джидинского месторождения (Западное Забайкалье) // Геоэкология, Инженерная геология, Гидрогеология, Геокриология. 2016. - № 3. - C. 241-251.

11. Geochemical and mineralogical aspects of sulfide mine tailings / M.B.J. Lindsay, M.C. Moncur, J.G. Bain, J.L. Jambor, C.J. Ptacek, D.W Blowes // Applied Geochemistry. - 2015. - V. 57. P. 157-177. DOI: 10.1016/j.apgeochem.2015.01.009.

12. Nordstrom D.K., Blowes D.W., Ptacek C.J. Hydrogeochemistry and microbiology of mine drainage: an update // Applied Geochemistry. - 2015. - V. 57. - P. 3-16. DOI: 10.1016/j.apgeochem.2015.02.008.

13. Mine waste acidic potential and distribution of antimony and arsenic in waters of the Xikuangshan mine, China / J. Zhou, тно-кальциевому, ведущая роль в смене которых принадлежит интенсивности водообмена.

Работа выполнена в рамках проекта IX.137.1.2. «Геохимия редких и редкоземельных элементов в природных и геотехногенных ландшафтах и гидрогеохимических системах».

M.T. Nyirenda, L. Xie, L. Baolong, Z. Yue, H. Liu // Applied Geochemistry. - 2017. - V. 77. - P. 52-61.

14. Добровольская М.Г., Гордеев В.И. Свинцово-цинковые месторождения // Месторождения Забайкалья / под ред. акад. Н.П. Лаверова. В 2 кн. - М.: Геоинформмарк, 1995. - Т. I. - Кн. I. - С. 70-92.

15. Геология и закономерности размещения эндогенных месторождений Забайкалья / Д.И. Горжевский, Н.А. Фогельман, Е.А. Алекторова и др. - М.: Недра, 1970. - 232 с.

16. Геологическая эволюция и самоорганизация системы вода-порода: в 5 т. Т. 2: Система вода-порода в условиях зоны гипергенеза / С.Л. Шварцев, Б.Н. Рыженко, В.А. Алексеев и др. Новосибирск: Изд-во СО РАН, 2007. - 389 с.

17. Гаррелс Р.М., Крайст Ч.Л. Растворы, минералы, равновесия. М.: Мир, 1968. - 368 с.

18. Замана Л.В., Чечель Л.П. Гидрогеохимические особенности зоны техногенеза полиметаллических месторождений ЮгоВосточного Забайкалья // Успехи современного естествознания. -2015 . - № 1-1. - С. 33-38.

19. Чечель Л.П. Эколого-гидрогеохимические последствия отработки вольфрамовых и молибденовых месторождений Восточного Забайкалья // Известия Томского политехнического университета. Инжиниринг георесурсов. - 2017. - Т. 328. - № 6. - С. 52-63.

20. The composition of Standard Seawater and the definition of the Reference-Composition Salinity Scale / F.J. Millero, R. Feistel, D.G. Wright, T.J. McDougall // Deep-Sea Research. - 2008. V. I. - № 55. - P. 50-72.

21. Гусева Н.В., Копылова Ю.Г., Леушина С.К. Распространенность редкоземельных элементов в природных водах междуречья Юньяхи и Ензорьяхи (Восточный склон Полярного Урала) // Вода: химия и экология. - 2012. - № 12 (54). - С. 121-129.

22. Еремин 0.В., Абрамов Б.Н. Распределение лантаноидов и иттрия в породах и карьерных водах Шерловогорского оловополиметаллического месторождения (Восточное Забайкалье) // Вода: химия и экология. - 2016. - № 1. - С. 18-23.

23. Шварцев С.Л. Гидрогеохимия зоны гипергенеза: 2-е изд., исправл. и доп. - М.: Недра, 1998. - 366 с.

24. Крайнов С.Р., Рыженко Б.Н., Швец В.М. Геохимия подземных вод. Теоретические, прикладные и экологические аспекты // под ред. академика Н.П. Лаверова. - М.: Наука, 2004. - 677 с.

25. Campbell K., Nordstrom D.K. Arsenic Speciation and Sorption in Natural Environments // Reviews in Mineralogy and Geochemistry. - 2014. - V. 79. - № 1. - P. 185-216. DOI: https://doi.org/10.2138/rmg.2014.79.3

26. Abdrakhmanov R.F., Akhmetov R.M. Hydrogeochemistry at mining districts // Geochemistry international. - 2016. - V. 54. № 9. - P. 795-806. DOI: 10.1134/S0016702916080024

27. Fate of Antimony and Arsenic in Contaminated Waters at the Abandoned Su Suergiu Mine (Sardinia, Italy) / R. Cidu, E. Dore, R. Biddau, D.K. Nordstrom // Mine Water and the Environment. - 2018. V. 37. - № 1. - P. 151-165. DOI: 10.1007/s10230-017-0479-8.

Поступила 05.06.2018 г.

\section{Информация об авторах}

Чечель Л.П., научный сотрудник лаборатории геоэкологии и гидрогеохимии Института природных ресурсов, экологии и криологии Сибирского отделения Российской академии наук.

Залана Л.В., кандидат геолого-минералогических наук, ведущий научный сотрудник лаборатории геоэкологии и гидрогеохимии Института природных ресурсов, экологии и криологии Сибирского отделения Российской академии наук. 
UDC 550.424.4

\title{
GEOCHEMICAL TYPES OF WATERS OF LEAD-ZINC DEPOSITS TAILINGS IN THE EASTERN TRANSBAIKALIA
}

\author{
Larissa P. Chechel', \\ Ipchechel@mail.ru \\ Leonid V. Zamana', \\ l.v.zamana@mail.ru \\ 1 Institute of Natural Resources, Ecology and Cryology of the Siberian branch of the Russian Academy of Sciences, \\ 16, Nedorezov street, Chita, 672014, Russia.
}

The relevance of the topic is caused by the need to solve the problem of conserving the quality of water resources in the conditions of mining impact.

The main aim of the research is to study chemical composition of technogenic-transformed waters in the areas of development of three lead-zinc deposits of Transbaikalia and their geochemical typification.

Objects of the research are the waters of tailings of lead-zinc deposits Blagodatskoe, Akatuevskoe and Kadainskoe, located in the Eastern Transbaikalia.

Methods. Concentrations of anions were measured by turbidimetric, potentiometric, colorimetric methods; cations and metals were determined by the atomic-adsorption method and inductively-coupled plasma mass spectrometry (ICP-MS). To determine the equilibrium composition of secondary mineral phases the authors have used the diagrams of the stability fields of aluminosilicate minerals, plotted by the method proposed by R.M. Garrels and C.L.Christ.

The results. According to the ratio of the main ions, the considered waters belong to hydro-carbonate, sulfate-hydro-carbonate, hydro-carbonate-sulfate and sulfate magnesium-calcium and calcium-magnesium chemical types. Drainage waters of lead-zinc deposits are characterized by significant excess of heavy metal contents ( $\mathrm{As}, \mathrm{Zn}, \mathrm{Cd}, \mathrm{Pb}, \mathrm{Sb}, \mathrm{Mn}, \mathrm{Mo}, \mathrm{U}, \mathrm{La}$, Se) over the average composition of leaching zone waters, with a maximum for arsenic more than 800 times and zinc- 200 times. The character of location of water composition points on the stability diagrams of the aluminosilicate minerals indicates their saturation with respect to clay aluminosilicates and calcite, that allows referring them to two geochemical types: silica-calcium-magnesium and siliceous carbonate-calcium, taking into account the peculiarities of their chemical composition. The change of these two types is caused by the intensity of water exchange. Typification of anomalous hydrogeochemical fields in mining regions is aimed at improving the ecological and geochemical monitoring of natural waters and can be used in developing measures to prevent pollution and purify waters.

\section{Key words:}

Lead-zinc deposits, technogenic waters, tailings, mineral equilibrium, geochemical type.

The research was carried out within the project IX.137.1.2. «Geochemistry of rare and rare earth elements in natural and geotechnogenic landscapes and hydrogeochemical systems».

\section{REFERENCES}

1. Amos R.T., Blowes D.W., Bailey B.L., Sego D.C., Smith L., Ritchie A.M. Waste-rock hydrogeology and geochemistry. Applied Geochemistry, 2015, vol. 57, pp. 140-156.

2. Alderton D.M., Serafimovski T., Mullen B., James S. The Chemistry of Waters Associated with Metal Mining in Macedonia. Mine Water and the Environment, 2005, vol. 24, no. 3, pp. 139-149.

3. McCarthy T.S. The impact of acid mine drainage in South Africa. South African Journal of Science, 2011, vol. 107, pp. 5-6.

4. Fawcett S.E., Jamieson H.E., Nordstrom D.K., McCleskey R.B. Arsenic and antimony geochemistry of mine wastes and associated waters and sediments at the Giant Mine, Yellowknife, Northwest Territories, Canada. Applied Geochemistry, 2015, vol. 62 , pp. 3-17.

5. Gavrishin A.I. Regularities in the formation of chemical composition of mine water and its influents on geological situation (Komissarovskaya mine, Earsten Donbass). Geoecology. Engineering geology. Hydrogeology. Geocryology, 2015, no. 6, pp. 505-513. In Rus.

6. Schastlivtcev E.L., Bykov A.A., Yukina N.I., Pushkin S.G. Assessment of anthropogenic impact on river basins in Kuzbass Mining Arias. Geoecology. Engineering geology. Hydrogeology. Geocryology, 2015, no. 4, pp. 333-339. In Rus.

7. Zamana L.V. Geochemistry of acidic drainage water of gold ore field of the East Trans-Baikal. Water: chemistry and ecology, 2013, no. 8, pp. 92-97. In Rus.
8. Xu X., Lin Y., Meng B., Feng X., Xu Z., Jiang Y., Zhong W., $\mathrm{Hu}$ Y., Qiu G. The impact of an abandoned mercury mine on the environment in the Xiushan region, Chongqing, southwestern China, Applied Geochemistry, 2018, vol. 88, part B, pp. 267-275.

9. SanPiN 2.1.7.1287-03. Sanitarno-epidemiologicheskie trebovaniya $k$ kachestou pochv $i$ gruntov [Sanitary rules and norms 2.1.7.1287-03. Sanitary and epidemiological requirements to the quality of soil and grounds] Available at: http://files.stroyinf.ru/Data1/11/11782/ (accessed 30 May 2018).

10. Doroshkevich S.G., Bardamova I.V. Phitotoxicity of tungstensulfide ore benefication tailings at Dzhidinskii ore deposit (the Western Cisbaikal region). Geoecology. Engineering geology. Hydrogeology. Geocryology, 2016, no. 3, pp. 241-251. In Rus.

11. Lindsay M.B.J., Moncur M.C., Bain J.G., Jambor J.L., Ptacek C.J., Blowes D.W Geochemical and mineralogical aspects of sulfide mine tailings. Applied Geochemistry, 2015, vol. 57, pp. 157-177.

12. Nordstrom D.K., Blowes D.W., Ptacek C.J. Hydrogeochemistry and microbiology of mine drainage: an update. Applied Geochemistry, 2015, vol. 57, pp. 3-16.

13. Zhou J., Nyirenda M.T., Xie L., Baolong L., Yue Z., Liu H. Mine waste acidic potential and distribution of antimony and arsenic in waters of the Xikuangshan mine, China. Applied Geochemistry, 2017, vol. 77, pp. 52-61.

14. Dobrovolskaya M.G., Gordeev V.I. Svintsovo-tsinkovye mestorozhdeniya [Lead-zinc deposits]. Mestorozhdeniya Zabaykalya 
[Deposits of Transbaikalia]. Ed. by N.P. Laverov. Moscow, Geoinformmark Publ., 1995. Vol. I, B. I, pp. 70-92.

15. Gorzhevskiy D.I., Fogelman N.A., Alektorova E.A. Geologiya $i$ zakonomernosti razmeshcheniya endogennykh mestorozhdeniy Zabaykalya [Geology and regularities of placement of endogenous deposits of Transbaikalia]. Moscow, Nedra Publ., 1970.232 p.

16. Shvartsev S.L., Ryzhenko B.N., Alekseev V.A. Geologicheskaya evolyutsiya i samoorganizatsiya sistemy voda-poroda. T. 2: Sistema voda-poroda $v$ usloviyakh zony gipergeneza [Geological evolution and self-organization of the water-rock system. Vol. 2: Water-rock system in the hypergenesis zone]. Novosibirsk, S0 RAN Publ., 2007. 389 p.

17. Garrels R.M., Krajst Ch.L. Rastvory, mineraly, ravnovesiya [Solutions, minerals, equilibria]. Moscow, Mir Publ., 1968. 368 p.

18. Zamana L.V., Chechel L.P. Hydrogeochemical features of the zone technogenesis polymetallic deposits Southeastern Transbaikalia. Advances in modern natural science, 2015, no. 1-1, pp. 33-38. In Rus.

19. Chechel L.P. Ecological and hydrochemical consequences of mining tungsten and molybdenum deposits of the eastern Transbaikalia. Bulletin of the Tomsk Polytechnic University. Geo Assets Engineering, 2017, vol. 328, no. 6, pp. 52-63. In Rus.

20. Millero F.J., Feistel R., Wright D.G., McDougall T.J. The composition of Standard Seawater and the definition of the ReferenceComposition Salinity Scale. Deep-Sea Research, 2008, vol. I, no. 55 , pp. 50-72.
21. Guseva N.V., Kopylova Yu.G., Leushina S.K. Dispersal of rare earth elements in natural water of interstream area of the rivers Yun'yakha and Enzor'yakha (East hang of the Polar Urals). $W a$ ter: chemistry and ecology, 2012, no. 12 (54), pp. 121-129. In Rus.

22. Eremin 0.V., Abramov B.N. The distribution of lanthanides and yttrium in the rocks and quarry waters of Sherlovogorskoe tin-polymetallic deposit (Eastern Transbaikalia). Water: chemistry and ecology, 2016, no. 1, pp. 18-23. In Rus.

23. Shvartsev S.L. Gidrogeokhimiya zony gipergeneza [Hydrogeochemistry of hypergenesis zone]. Moscow, Nedra Publ., 1998. 366 p.

24. Krainov S.R., Ryzhenko B.N., Shvets V.M. Geokhimiya podzemnykh vod. Teoreticheskie, prikladnye $i$ ekologicheskie aspekty [Geochemistry of groundwater. Theoretical, applied and ecological aspects]. Moscow, Nauka Publ., 2004. 677 p.

25. Campbell K., Nordstrom D.K. Arsenic Speciation and Sorption in Natural Environments. Reviews in Mineralogy and Geochemistry, 2014, v. 79, no. 1, pp. 185-216.

26. Abdrakhmanov R.F., Akhmetov R.M. Hydrogeochemistry at mining districts. Geochemistry international, 2016, vol. 54, no. 9, pp. 795-806.

27. Cidu R., Dore E., Biddau R., Nordstrom D.K. Fate of Antimony and Arsenic in Contaminated Waters at the Abandoned Su Suergiu Mine (Sardinia, Italy). Mine Water and the Environment, 2018, v. 37 , no. 1, pp. 151-165.

Received: 5 June 2018.

\section{Information about the authors}

Larissa P. Chechel, researcher, Institute of Natural Resources, Ecology and Cryology of the Siberian branch of the Russian Academy of Sciences.

Leonid V.Zamana, Cand. Sc., leading researcher, Institute of Natural Resources, Ecology and Cryology of the Siberian branch of the Russian Academy of Sciences. 